\title{
Cytogenetic polymorphism of english oak (Quercus robur L.) seedlings from areas with different levels of anthropogenic pollution
}

\author{
By V. N. Kalaev and A. A. Popova*)
}

(Received 28 $8^{\text {th }}$ April 2014)

\begin{abstract}
Cytogenetic polymorphism of English oak seedlings from areas with different levels of anthropogenic pollution was studied. In each studied area, groups of seedlings with low, intermediate, and high level of mutations have been identified. Mutable groups were characterised by a high level of mitotic pathologies, broad spectrum of such pathologies (e.g., chromosome agglutination, asymmetric and tripolar mitoses). Impact of trees location near the freeway leads to variability increase of cytogenetic properties and domination of intermediate-mutable groups of seedlings.
\end{abstract}

Key words: cytogenetic polymorphism, English oak, anthropogenic pollution, mitotic activity, pathologies of mitosis, nucleolar characteristics.

\section{Introduction}

Tree cytogenetics has been extensively studied during the past few years (PAVLICA et al., 2000; PRUs-GlowACKI et al., 2006; RIBEIRO et al., 2008; LIC̆INA et al., 2013; SILVESTRINI et al., 2013; MuRATOVA et al., 2007; MiLYutin et al., 2004; OUdALOVA and GERAS'KIn, 2012; KALASHNIK and Yasovieva, 2012). Cytogenetic methods have been proven to be both informative and sensitive (BoRZAN et al., 1996; Butorina and Evstratov, 1996; LuOMAJOKI, 1996; Milller and GRILl, 1996). Thus, cytogenetic polymorphism of weeping birch and Scots pine seedlings was demonstrated based on their mitotic parameters and nucleolar characteristics (SENKEVICH, 2007; KALAEV et al., 2010) The studies of cytogenetic response of English oak seedlings to the long-term radioactive pollution resulting from the Chernobyl accident showed changes in cell proliferation rates and nucleolar characteristics, together with the wave kinetics of the mutation (ARTYUKHOV and KALAEV, 2006). It should be noted that increased variability of cytogenetic parameters in the studied areas $\left(9^{\text {th }} \mathrm{km}\right.$ of the Zadonsk freeway, Usmanskii forest) indicated cytogenetic heterogeneity of seedlings and suggested the existence of groups with different levels of genetic material stability, as it has been shown in previous studies on weeping birch and Scots pine (KALAEV et al., 2010).

Since Quercus species widely grow on almost every continent (AXELROD, 1983), studying cytogenetic variability in oak populations might help to elucidate the mechanisms of adaptation and population stability maintenance.

\footnotetext{
*) Corresponding author: A. A. PopovA. Lecturer of Department of Botany and Plant Physiology of Voronezh State Forestry University. Tel. +7(473)2537388. E-Mail: logachevaaa@rambler.ru
}

The purpose of our research was to determine cytogenetic characteristic variation among seedlings from English oak trees growing in areas that differed in the extent of anthropogenic factors on the environment.

\section{Materials and Methods}

Acorns of English oak (Quercus robur L.) were collected in the area of the $9^{\text {th }} \mathrm{km}$ of the Zadonsk freeway. To estimate direct effect of vehicle emissions on the seedlings, acorns were collected from areas with different levels of pollution. Plot 1 was located deep in the forest (approximately $1 \mathrm{~km}$ from the freeway) and was considered relatively clean area. Plot 2 was located near the freeway and was characterized by a high level of air pollution caused by car exhaust fumes. The areas near the freeway were characterized by a presence of nitrogen dioxide, phenol, and other chemical substances at the levels exceeding maximum allowable concentrations (MACs) for these compounds (CHYBIRKo and STEPKIN, 2009). According to the Department of Nuclear Physics of the Voronezh State University, all plots have been exposed to radioactive contamination resulting from the Chernobyl accident in 1986, when gamma-radiation background reached $200 \mu \mathrm{R} / \mathrm{h}$. At the time of acorn collection, the background radiation in this area didn't exceed $14 \mu \mathrm{R} / \mathrm{h}$.

The age of oak trees in these natural stands was about 100 years. Acorns (150-200 from 5-15 different trees for each plot) were collected and germinated in moist sand. When the seedling roots reached a length of 2 to $3 \mathrm{~cm}$, they were fixed in a 3:1 mixture of $95 \%$ ethanol and glacial acetic acid. The samples were fixed 22 hoursafter emergence, when the peak of mitotic activity took place (BUTORINA and KALAEV, 1998). The obtained preparations were kept refrigerated at $4^{\circ} \mathrm{C}$. The roots were stained by acetic-haematoxylin squash method as described earlier (BUTORINA and KALAEV, 1998).

Total of 46 preparations were made (17-from plot 1 ; 29-from plot 2). Cytological analysis were performed using a Laboval-4 microscope (Carl Zeiss, Jena) at magnification of $40 \times 1.5 \times 10$ or $100 \times 1.5 \times 10$ to study nucleolar characteristics (150 cells) and mitoses (no less than 700 cells).

In each preparates the total number of cells, the number of dividing cells in each mitotic stage, and the number of cells with pathological mitoses were recorded. Mitotic activity was estimated by calculating mitotic index, i.e., the ratio between the number of dividing cells and total number of analyzed cells. Mitotic index was counted as the ratio between the number of cells at the metaphase, anaphase, and telophase to the total 


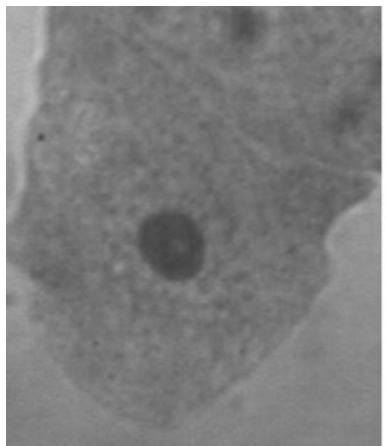

a

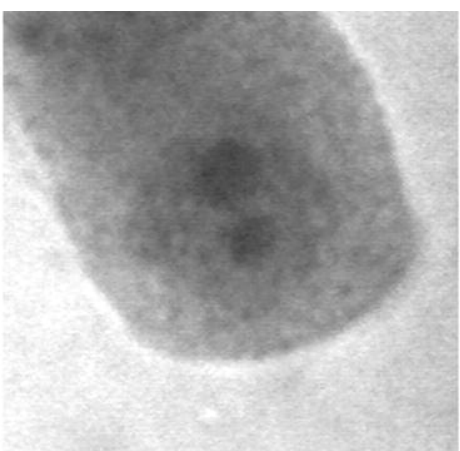

b

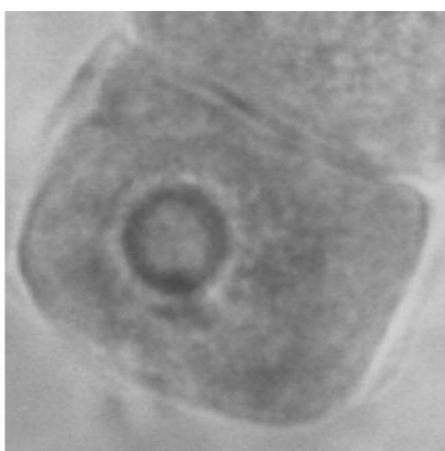

C

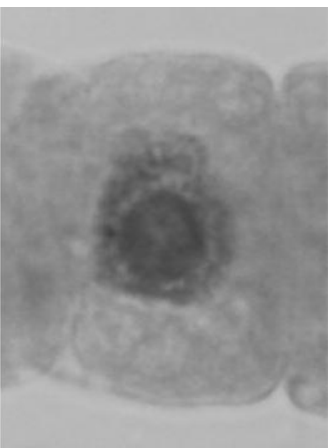

d

Figure 1. - Types of nucleoli in apical meristem cells of the seedlings from acorns of oak (Quercus robur L.): A - vacuolated; B - compact type; C - "Bark-core" vacuolated; D -"Bark-core" type.

number of analysed cells) excluding prophase cells (KALAEV, 2000). We calculated the percentage of cells at the prophase, metaphase, and anaphase-telophase stages; the percentage of pathological mitoses out of the total number of cell divisions, and the percentage of pathologies at metaphase, anaphase, telophase out of the total number of aberrant cells at these three stages of mitosis combined (as the majority of pathologies are recorded at these mitotic stages); the percentage of each type of mitotic pathology out of total number of pathologies, and the percentage of cells with persistent nucleoli at the metaphase - anaphase stages out of total number of cells at these stages. Mitotic pathologies were classified according to Alov (Alov, 1965).

As the size of nucleoli depends directly on the level of ribosomal gene activity (SANS et al., 1984), such nucleolar characteristics as surface of area of single nucleoli and occurrence of various nucleolus types were studied. The percentage of persistent nucleoli in dividing cells was estimated. To calculate the nucleoli surface area (in $\mu_{\mathrm{m}}^{2}$ ), we measured diameters of nucleoli using ocular micrometer (150 cells were analyzed in each prepa-

Table 1. - Cytogenetic parameters of English oak seedlings from trees growing in the areas with different levels of anthropogenic pollution.

\begin{tabular}{|c|c|c|c|c|}
\hline \multirow[b]{3}{*}{ Cytogenetic parameter } & \multicolumn{4}{|c|}{ Experimental plots } \\
\hline & \multicolumn{2}{|c|}{ Plot 1 -decp it the forest } & \multicolumn{2}{|c|}{ Plot 2 - near ftecway } \\
\hline & $\bar{x} \pm s_{x}$ & $C \%$ & $\bar{x} \pm s$ & $C \%$ \\
\hline Mitolic index, $\%$ & $7,5 \pm 0,3$ & 17,3 & $8,4 \pm 0,3$ & 22.6 \\
\hline Mitotic index excluding prophase cells, $\%$ & $5,1 \pm 0,3$ & 23,5 & $5,2 \pm 0,3$ & 30,8 \\
\hline Prophase cells, \% & $31.8 \pm 3.8$ & 48,7 & $38.3 \pm 2,6$ & 36.8 \\
\hline Metaphase cells, \% & $27,5 \pm 1,9$ & 28 & $20,5 \pm 1,1$ & 29,8 \\
\hline Anich hase-telophase cells, $\%$ & $40,7 \pm 1,3$ & 23,8 & $41.2 \pm 2,0$ & 25.7 \\
\hline Mitolie pathologies. \% & $11.3 \pm 1,3$ & 55.6 & $11,6 \pm 1.0$ & 44.8 \\
\hline Mitotic pathologies excluding proplase cells, $\%$ & $16,012,2$ & 48,7 & $19,1 \pm 1,6$ & 44,0 \\
\hline Area surface of nucleoli of the "core-bark" typc, $\mu \mathrm{m}^{2}$ & $65,5 \pm 3.6$ & 22,4 & $65,0 \pm 2,7$ & 21.8 \\
\hline $\begin{array}{l}\text { Area surface of nueleoli of the "core-bark" vacuolated type, } \\
\mu_{\mathrm{m} 1}{ }^{2}\end{array}$ & $79.7 \pm 3,6$ & 18.6 & $86,8 \pm 3.0$ & \\
\hline Area surface of nucleoli of the vacuolated type, $\mu \mathrm{m}^{2}$ & $52,2 \pm 13,2$ & 61,7 & $61,0 \pm 6.7$ & 45,3 \\
\hline Area surlace of nuclesli of the compace type, $\mu \mathrm{m}^{2}$ & $4.3,3 \pm 5,3$ & 36,7 & $39,6 \pm 3,7$ & 35.1 \\
\hline Area surface of single nucleoli, $\mu \mathrm{m}^{2}$ & $75,6 \pm 3,7$ & 20,4 & $82,4 \pm 2,9$ & 19,3 \\
\hline Cells with nucleoli of the "core-bark" type, \% & $27,7 \pm 3,3$ & 49,1 & $19,3 \pm 2,0$ & 61,1 \\
\hline Cells with nucleoli of the "core-batk" vacuolited type, $\%$ & $71,1 \pm 3,5$ & 20,1 & $78.9 \pm 2.3$ & 15.6 \\
\hline Cells with nucleoli of the vacuolated type, $\%$ & $0,6 \pm 0.2$ & 150 & $3,6 \pm 2,7$ & 402.7 \\
\hline Cells with compact nucleoli, $\%$ & $0,7 \pm 0,2$ & 128,6 & $2,6 \pm 1,7$ & 353.8 \\
\hline
\end{tabular}




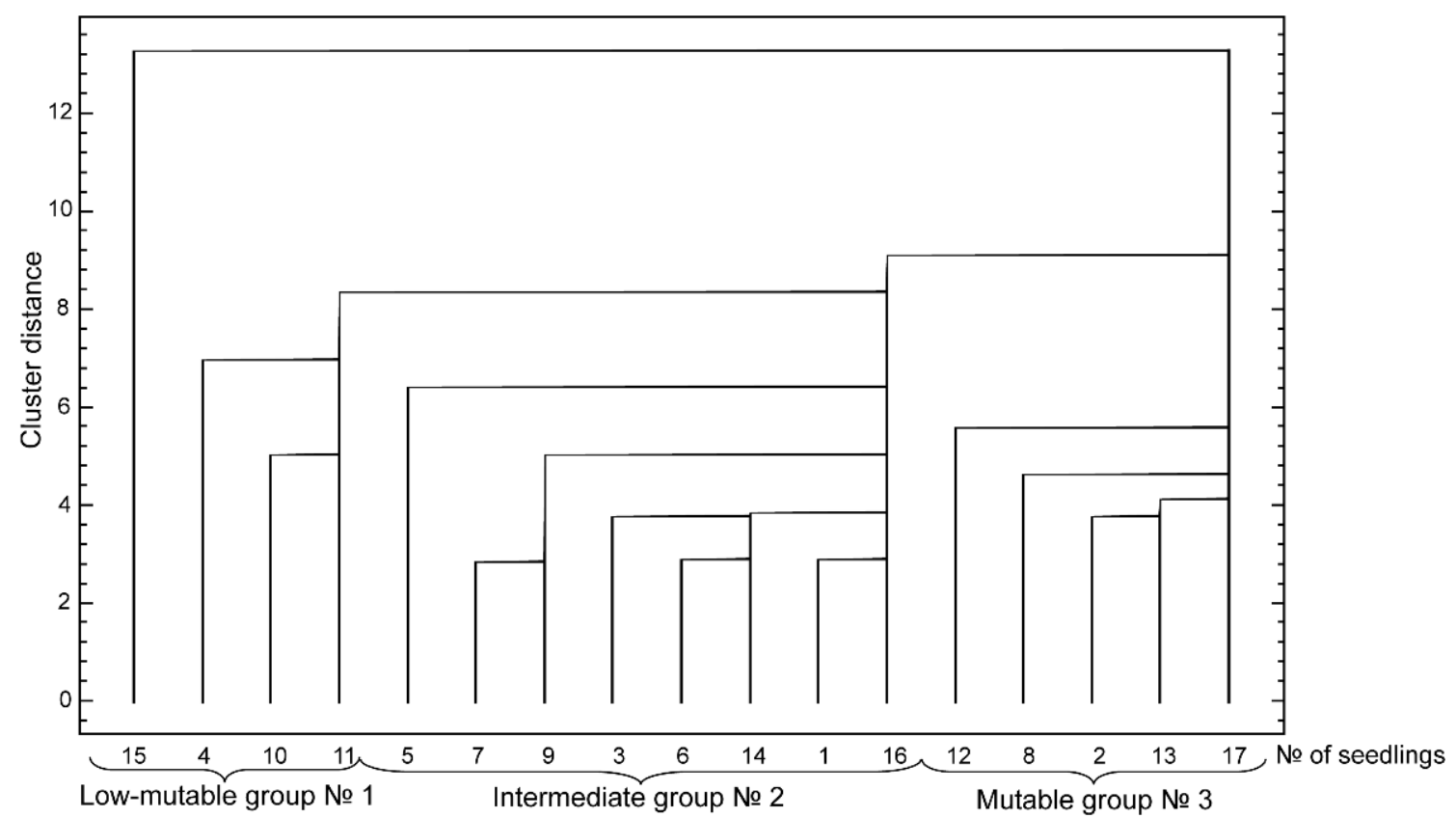

Figure 2. - Dendrogram of cluster distances between English oak seedlings from deep forest (plot 1) based on their cytogenetic properties.

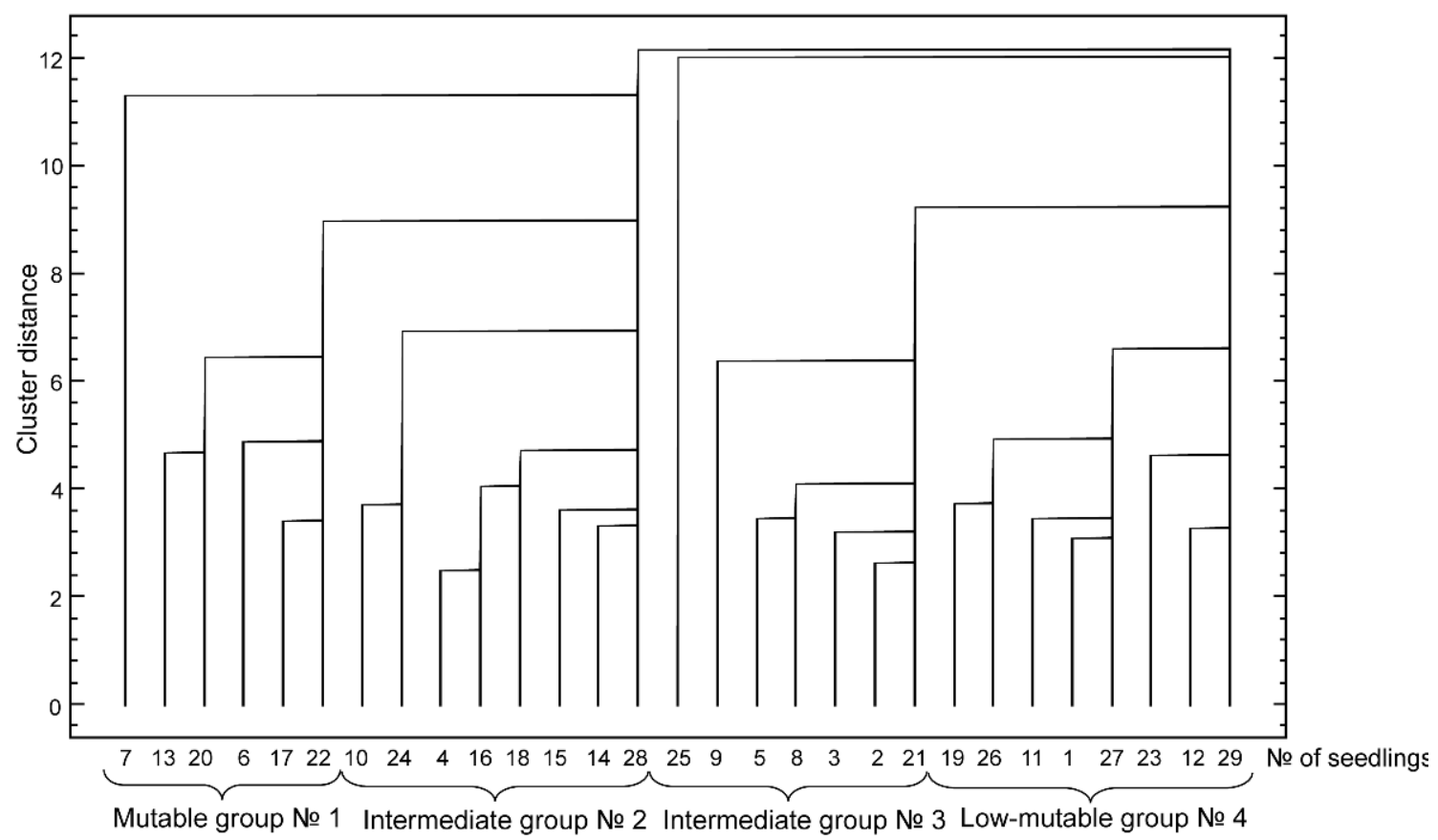

Figure 3. - Dendrogram of cluster distances between English oak seedlings from seeds collected near freeway (plot 2) based on their cytogenetic properties.

ration of root meristem). The percentage of various nucleolus types was determined as the ratio between the number of cells with a particular nucleolus types to the total number of analyzed cells. Nucleoli were classified according to CHELIDZE and ZATCEPINA (CHELIDZE and ZATCEPINA, 1988). The following types of nucleoli were identified: "bark-core", compact, "bark-core" vacuolated, and vacuolated (Fig. 1). The first two nucleolar types are considered highly active, the last two - moderately active. Compact nucleoli are the most active form of nucleoli, under light microscopy it shown as homogeneous. It has high level of granular component. „Bark- 
Table 2. - Cytogenetic parameters of oak seedlings from plot 1 trees in the identified groups with different stability of genetic material.

\begin{tabular}{|c|c|c|c|}
\hline Cylogenctic parameter's & & Secdling group & \\
\hline Mitotic index (including prophase cells). \% & $\begin{array}{l}\text { Low-mutable Ni } 1 \\
6,8 \pm 0.5\end{array}$ & $\begin{array}{l}\text { Internediate } 1 \underline{2} 2 \\
7,5 \pm 0,5\end{array}$ & $\begin{array}{l}\text { Mutable Na } 3 \\
8,1 \pm 0.6\end{array}$ \\
\hline Milotic index (excluding prophase cells), \% & $4,2 \pm 1,1$ & $5.3 \pm 0.2$ & $5,5 \pm 0,3$ \\
\hline Prophase eells, $\%$ & $41,1 \pm 1,13,9$ & $27,4 \pm 3,6$ & $31.5 \pm 3,7$ \\
\hline $\begin{array}{l}\text { Melaphuse cellh, } \% \\
\text { Anaphasc-cclophase cells, } \%\end{array}$ & $\begin{array}{l}22,9 \pm 5,6 \\
36,0 \pm 8.7\end{array}$ & $\begin{array}{l}30,1 \pm 2,1 \\
42,5 \pm 2,7\end{array}$ & $\begin{array}{l}26.9 \pm 3,1 \\
11.6 \pm 2,1\end{array}$ \\
\hline 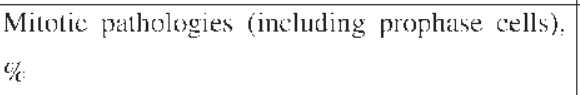 & $10,0 \pm 1,7$ & $8,3 \pm 1,3$ & $17: 1 \pm 2,3$ \\
\hline $\begin{array}{l}\text { Mitotic pathologies (cxeluding prophase colls), } \\
\text { }\end{array}$ & $11.7 \pm 4.2$ & $12,4 \pm 1,8$ & $25,2 \pm 3,7$ \\
\hline Area surface ol single nucleoli & $69,6 \pm 9,5$ & $69.0 \pm 3.7$ & $91,2 \pm 3,5$ \\
\hline $\begin{array}{l}\text { Ared surface of nucleoli of" the "corc-hark" type, } \\
\mu^{2}\end{array}$ & $61.6 \pm 8.1$ & $59,4 \pm 3,9$ & $78,4 \pm 5,5$ \\
\hline $\begin{array}{l}\text { Area surlace of nucleoli of the "core-bark" } \\
\text { vacuolated typo, } \mu \mathrm{m}^{2}\end{array}$ & $74,9 \pm 8,3$ & $28,3 \pm 0$ & $95.1 \pm 4,0$ \\
\hline $\begin{array}{l}\text { Area surface of nucleoli of the vacuolated type, } \\
\mu^{2}{ }^{2}\end{array}$ & $64,2 \pm 1,7$ & $44.7 \pm 4,6$ & 0 \\
\hline $\begin{array}{l}\text { Areid surface of nucleoli of the compact type, } \\
\mu \mathrm{tr}^{2}\end{array}$ & $38.4+4.9$ & $11,2+7,4$ & $48,7+15,9$ \\
\hline Cells with nucleoli of the "core-bark" type, $\%$ & $34,3 \pm 12,3$ & $27,0 \pm 3,0$ & $23.6 \pm 4.4$ \\
\hline $\begin{array}{l}\text { Cells with nucleoli of the "core bark" } \\
\text { vacuolaticd lype, } \theta\end{array}$ & $62,2 \pm 12,9$ & $72.5 \pm 7,0$ & $75,9 \pm 4,4$ \\
\hline Cells with nucleoli of the vacuolated type, $\%$ & $1.9 \pm 0.6$ & $0,3 \pm 0,2$ & 0 \\
\hline Colls with compact nuclcoli, & $1,7 \pm 0,6$ & $(0,3 \pm 0,2$ & $0,5 \pm 0,2$ \\
\hline
\end{tabular}

core" nucleoli are high active form of nucleoli, typical for cells with high level of rRNA and protein synthesis. Nucleoli have central part with fibril component and periphery granular component. Vacuolated nucleoli have average active, vacuolated component prevails over the ribonucleoprotein-component in their structure. "Barkcore" vacuolated nucleoli can be attributed to the group of vacuolated nucleoli and has moderate activity.

The results were processed statistically using the STADIA software package. The following cytogenetic characteristics of English oak seedlings were compared: occurrence of cells with mitotic pathologies (using the Van der Waerden rank test, as the distribution of these values was nonparametric), mitotic index, percentage of cells at different stages of mitosis, and nucleolar characteristics (using the parametric Student's $t$-test). The percentage contents of different types of mitotic pathologies were compared using Z-test approximation for equal frequency criterion. Cluster analysis was conducted using normalized Euclidean distances and complete linkage classification method. The following cytogenetic parameters of all seedlings from each plot were entered in the data matrix: mitotic index calculated either including or excluding prophase cells (\%), percentage of cells at the prophase, metaphase, and anaphase-telophase stages, percentage of cells with mitotic pathologies calculated either including or excluding prophase cells, percentage of cells with various nucleolus types, surface area of single nucleoli $\left(\mu^{2}\right)$. The validity of performed classification was confirmed by discriminant analysis using Mahalanobis distances. Coefficient of variation $(C v)$ was calculated according to LAKIN (LAKIN, 1990). $C v$ over $25 \%$ was regarded as high, from 10 to $25 \%$ - as moderate, under $10 \%$ - as low (LAKIN, 1990). The influence of group factor identified by cluster analysis on the cytogenetic properties of seedlings was estimated by oneway variance analysis. The power of influence was estimated according to Snedecor (in \%). 


\section{Results}

Cytogenetic properties of English oak seedlings from trees growing on areas with different levels of anthropogenic pollution are shown in Table 1. The pathology of mitosis increased, appear agglutination of chromosomes, tripolar mitoses, mitotic index increased by expense of delay cells at the stage of prophase in the cells of the apical meristem of seedlings on the territory of the road. At this site significantly increases the surface area of a single nucleoli, among nucleolar characteristics. The surface area highly active nucleoli "core-bark" type is reduced, the surface area of moderately active nucleoli ("core-bark" vacuolated type) increases. It can be noted for this area also increase the percentage of rare oak nucleoli type - compact and vacuolation, which may indicate the activation of reserves synthetic apparatus of the cell. Thus, growing conditions, where impact of transport is a high, have stressful effects on plants. The reaction of plants is shown in the violation of mitotic division and its intensification to correct the accumulated violations at the cellular level.
The coefficient of variation $C v$ for such parameters as mitotic index (calculated either including or excluding prophase cells); percentage of cells at the prophase and metaphase stages, mitotic pathologies (calculated either including or excluding prophase cells) exceeded $25 \%$, which might indicate genetic heterogeneity of the studied oak seedlings. To identify seedling groups within the population, we used the cluster analysis method (Figs. 2 and 3 ). In both experimental (plots 1,2) groups with different levels of mitotic abnormalities were revealed. Seedlings with high level of mitotic pathologies were regarded as a mutable group, seedlings with low levels of pathologies - as a low-mutable group, with the intermediate group in between (Tables 2 and 3 ).

The influence of the group factor on the majority of studied cytogenetic parameters was found (Table 4).

Mutable groups were characterised by a high level of mitotic pathologies, broad spectrum of such pathologies (e.g., chromosome agglutination, asymmetric and tripolar mitoses), and lower level of mitotic activity as compared to the low-mutable groups. Low-mutable groups

Table 3. - Cytogenetic parameters of oak seedlings from plot 2 trees in the identified groups with different stability of genetic material.

\begin{tabular}{|c|c|c|c|c|}
\hline Cytogenetic parameters & \multicolumn{4}{|c|}{ Secolling group } \\
\hline Milotic index (including prophase eclls). \% & $7, \mathrm{I} \pm \mathrm{I}, 0$ & $9_{1} 1 \pm 0,6$ & $8,7 \pm 0,5$ & $8,3 \pm 0,6$ \\
\hline Mitotic index (cxcluding prophasc cells), $\%$ & $4,1 \pm 0,8$ & $6,3 \pm 0,5$ & $4,9 \pm 0,5$ & $5,1 \pm 0,3$ \\
\hline Metcphase cells, $\%$ & $22,1 \pm 2,9$ & $22.4 \pm 1.7$ & $17.8 \pm 2.7$ & $20,0 \pm 1.9$ \\
\hline Anaphase-telophase cells, $\%$ & $48,5 \pm 7.9$ & $36,6 \pm 2,9$ & $48.9 \pm 4.7$ & $41,9 \pm 3,7$ \\
\hline $\begin{array}{l}\text { Mitotic pathologies (including prophase cells), } \\
\text { \% }\end{array}$ & $14,9 \pm 2.4$ & $12,5 \pm 1,5$ & $8.0 \pm 2,3$ & {$[1,3 \pm 1,1$} \\
\hline Atea surface of single nucleoli & $67,0 \pm 4,4$ & $72.8 \pm 1.5$ & $89,3 \pm 3,8$ & $97.5 \pm 5.1$ \\
\hline $\begin{array}{l}\text { Area surface of mucleoli of the "cote-batk" } \\
\text { Lype, um" }\end{array}$ & $56,8 \pm 3,3$ & $54,7 \pm 4,0$ & $70,4 \pm 4,9$ & $76,6 \pm 3,9$ \\
\hline $\begin{array}{l}\text { Area surtace of nucleoli of the "core-bark" } \\
\text { vacuolated type, } \mu \mathrm{m}^{\text {? }}\end{array}$ & $7,9,3 \pm 5,5$ & $76.3 \pm 2,1$ & $92.2 \pm 3.9$ & $102,6 \pm 5,0$ \\
\hline $\begin{array}{l}\text { Area surface of nuclendi of the racuolated } \\
\text { type, } \mu \mathrm{m}^{\text {? }}\end{array}$ & $29.0 \pm 0.7$ & $37,29 \pm 7.6$ & $64,4 \pm 8.2$ & $84,1+5.2$ \\
\hline $\begin{array}{l}\text { Area surlace of nucleol of the compant lype } \\
\mu \mathrm{m}^{2}\end{array}$ & $44,5+6,3$ & $33,0+11,7$ & $42,9+4,2$ & $36,11+5,9$ \\
\hline Cells with nucleoli of the vacuolated type, $\%$ & $0,6 \pm 0,3$ & $0.7 \pm 0,3$ & $11,3111,2$ & $1.9 \pm 0,4$ \\
\hline Cells with compact nucleoli, & $2,0 \pm 0,5$ & $0,5 \pm 0,4$ & $7,5 \pm 7.1$ & $0,8 \pm 0,3$ \\
\hline
\end{tabular}


Table 4. - The influence (\%) of group factor on cytogenetic parameters of oak seedlings from trees growing in areas with different levels of anthropogenic pollution.

\begin{tabular}{|c|c|c|}
\hline \multirow[t]{2}{*}{ Cytogenetic parameter } & \multicolumn{2}{|c|}{ Experimental plots } \\
\hline & Plot $1-$ deep in the forest & Plot 2 - near the freceway \\
\hline Mitotic index (including prophase cells), $\%$ & 0 & 0 \\
\hline Mitotic index (excluding prophase cells), $\%$ & 0 & $1^{*}$ \\
\hline Prophase cells, \% & 0 & 0 \\
\hline Metaphase cells, \% & 0 & 0 \\
\hline Anaphase-telophase cells, $\%$ & $1:: \div$ & $10^{*}$ \\
\hline Mitotic pathologies (including prophase cells), $\not$ & $2 *$ & 0 \\
\hline Mitotic pathologics (cxcluding prophasc cells), & 0 & 0 \\
\hline Area surface of single nucleoli & $10^{*}$ & 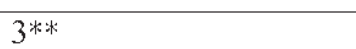 \\
\hline Area surface of nuclcoli of the "core-bark" type, $\mu \mathrm{m}^{2}$ & $1 *$ & $4 * * *$ \\
\hline Area surface of nucleoli ol the "core-bark" vacuolated type, $\mathrm{m}^{2}$ & $10^{\text {F***1 }}$ & $8 * * *$ \\
\hline Area surface of nucleoli of the vacuolated type, $\mu \mathrm{m}^{2}$ & 0 & 0 \\
\hline Area surface of nucleoli of the compact type, $\mu_{\mathrm{m}}{ }^{2}$ & $3^{* / *}$ & $6^{* * * * *}$ \\
\hline Cclls with nucleoli of the "core-bark" type, of & 0 & $5^{* k * k}$ \\
\hline Cells with nucleoli of the "core-bark" vacuolated type, $\%$ & 0 & 7 非水妵 \\
\hline Cells with nucleoli of the vacuolatod type, of & $8 * *$ & 0 \\
\hline Cells with compact nuclcoli, $\%$ & 5 类 & 0 \\
\hline
\end{tabular}

${ }^{*} \mathrm{p}<0.05,{ }^{* *} \mathrm{p}<0.01,{ }^{* * *} \mathrm{p}<0.001$.

were characterised by a low percentage of cells with mitotic pathologies, narrower spectrum of pathologies (agglutination of chromosomes, tripolar mitoses are absent), and high levels of mitotic activity. Intermediate groups were characterised by a moderate level of mitotic pathologies, but the other properties varied depending on the studied seedling population. No trends in nucleolar characteristics variations have been revealed. Intermediate groups dominated in bough plots. The percentage of intermediate group seedlings was $47.1 \%$ (plot 1) and $51.7 \%$ (plot 2). The percentage contents of mutable groups for seedlings from plots 1 (deep forest) and 2 (freeway) comprised 29.4 and $20.7 \%$, respectably. The percentage contents of low-mutable groups for seedlings from plots 1 and 2 comprised 23.5 and $27.6 \%$, respectably.

\section{Discussion}

The data obtained prove the existence of English oak seedling phenotypic characteristic variability at the cellular level. Earlier, both protein and genetic polymorphism has been demonstrated for Quercus species. Thus, allozymes variability for 6-phosphogluconate dehydrogenase, shikimate dehydrogenase, NADH dehydrogenase, malate dehydrogenase, malic enzyme, and other enzymes has been found in the isolated populations at the east boundary of English oak habitat (Mullagulov et al., 2008). Analysis of pollen proteins in Q. ilex (GALVAN et al., 2012) confirmed the earlier data on plant variability obtained by studying acorn morphology and protein profiling. For $Q$. acutissima, genetic variability was found to exist mainly within the population (84\%) (ZHANG, 2013). The study of chloroplast DNA of $Q$. variabilis plants also revealed significant intrapopulational genetic variability (CHEN et al., 2012). Taken together, the abovementioned data show that Quercus specimens have high intrapopulational variability at the gene, protein, cell, tissue, and organ levels.

On our opinion, high heterogeneity of any characteristic within a population helps species to survive. Polymorphism becomes a powerful survival factor undo environmental conditions change, especially when technogenic and anthropogenic pressure on the ecosystem as a whole or on its individual components increases. Selection of variants most adaptable to new conditions leads to the shift in the mean values of quantitative parameters. (SIMAKOv, 1983). On other hand it has 
repeatedly been indicated, what the increase of "adaptation potential" may be associated with a decrease of the variability in the population.

The functioning of ecosystems, in its turn, is supported by a variety of plant species, which in particular can be provided by genetic variety within a species (CASTAGNEYROL et al., 2012).

Here we studied oak seedling populations from areas differing in the level of anthropogenic pressure. The four groups of seedlings were revealed to plot 2 (near the freeway), unlike the three - plot 1 (deep in the forest), due to the additional intermediate groups of seedlings. The nucleolar parameters of intermediate groups were differ (plot 2). Thus the impact of vehicles leads to increase the percentage of seedlings from intermediate groups, to increase the number of mitosis pathologies.

This assumption is consistent with some previous studies that demonstrated changes in the activity of nucleolar organizer regions in various plant species during adaptation to stress (SoBoL', 2001). The increase in the number of groups among seedlings in the area near freeway is consistent with earlier studies of coniferous plants cytogenetic variability - the adaptation processes in Scots pine populations were activated under anthropogenic pressure (GERAS'KIN and VASIL'EV, 2005).

Earlier studies of cytogenetic polymorphism of weeping birch (Betula pendula Roth) and Scots pine (Pinus sylvestris) also revealed three seedling group types: mutable, low-mutable and intermediate (KALAEV et al., 2010). The mutable group was characterised by a high level of mitotic pathologies and increased surface area of single nucleoli during the interphase. The mitotic pathologies included tripolar metaphase and asymmetric mitosis, which were found in this group only. The observed high levels of mitotic pathologies and a broader spectrum of such pathologies in mutable groups are consistent with the data obtained in our study. In the low-mutable group, anaphase bridges dominated among mitotic pathologies, which according to some authors (AKOPIAN, 1967; SIMAKOV, 1983), proves the active functioning of DNA repair systems. Intermediate groups were characterized by intermediate values of the studied cytogenetic parameters. Numerous studies show that in $P$. sylvestris and $B$. pendula at the contaminated areas more total mutations were observed and seedlings from the ecologically clean areas has the high level of mitotic activity and a low ratio of pathilogys of mitosis. At the same time number of seedlings in mutable groups are higer at clear area because very low mutation activity in other groups. In contrast to these data, our study showed that for the English oak seedlings, intermediate groups dominated both in contaminated and clean areas. Another distinctive difference of Scots pine seedlings from the mutable group was the absence of delays during mitotic phases, which can be explained by the nonfunctioning checkpoint systems for maintaining chromosomal integrity.

Our study revealed two types of changes in nucleolar characteristics of seedlings from intermediate groups in polluted area, which were not typical for Scots pine and weeping birch seedlings.
Comparison of cytogenetic polymorphism of two angiosperm and one gymnosperm species of woody plants reveals a general trend of separation of seedlings into groups with different mutability levels. Since studied species (B. pendula Roth, $Q$. robur L.) belong to different families, the discrepancies in relative contents of mutable, low-mutable and intermediate groups in the areas with different levels of anthropogenic pressure, as well as differences in the changes in cytogenetic parameters within the groups, can be explained by speciesspecific characteristics. However, the existence of these groups is a distinctive feature of seedlings of woody plants. The study of phenotypic flexibility and ecological adaptation of cork oak has shown that seedlings retain physiological parameters of parent trees even when exposed to different conditions (RAMIEZ-VALIENTE et al., 2010). Considering the possibility of characteristic preservation by inheritance, the data on cytogenetic variations could be used in forest selection (mutable progeny selection) and forestation using plants with stable genetic apparatus (low-mutable progeny).

\section{Acknowledgments}

The work was supported by the Ministry of Education and Science of Russia within the framework of the State Assessment in Science 2015/18 for Voronezh State University (Project No. 1035).

\section{References}

AKopian, E. (1967): Effect of different types of ionizing radiation on the occurrence of chromosomal aberrations in pea. I. Postradiation recovery. Russ. J. Genet 3(5): 45-51.

Alov, I. A. (1965): Mechanisms of mitosis pathology. Vestn Akad Med Nauk SSSR. 1966; 21(11): 3-13.

Artyukhov, V. G. and V. N. Kalaev (2006): Cytogenetic indices of English oak (Quercus robur L.) seminal progeny subject to radioactive radiation in the Chernobyl nuclear disaster and growing on territories with different levels of anthropogenic contamination, pp. 247-264 in 20 Years after Chernobyl Accident: past, present and future, edited by E. B. BuRlakova, V. I. NAIDICH, Nova Science Publishers, Inc., New York.

AxelRoD, D. (1983): Biogeography of oaks in the ArctoTertiary province. Ann. Missouri Bot. Gard. 70: 629-657.

Borzan, K., M. Idzojtic and H. GutTEnBerger (1996): Standardization of gymnosperm karyotypes using Picea omorika as an example. Forest Genetics 3(3): 127-136.

Butorina, A. and N. Evstratov (1996): The first detected case of amitosis in pine. Forest Genetics 3(3): 137-139.

Butorina, A. and V. Kalaev (1998): Diversity of Cytological Characteristics in Oak Under Normal Conditions, pp. 46-48 in Diversity and Adaptation in Oak Species. Proceedings of a conference of IUFRO Working Party 2.08.05 held Oct. 12-17, Pennsylvania, U.S.A., Pennsylvania.

Castagneyrol, B., L. Lagache, B. Giffard, A. Kremer and H. JACTEL (2012): Genetic diversity increases insect herbivory on oak saplings. PloS One. DOI 10.1371/journal.pone.0044247. 
Chelidze, P. V. and O. V. Zatcepina (1988): Morphofunctional classification of nucleoli. Uspekhi Sovr. Biol. 105(2): 252-267. (In Russian)

Chen, D., X. Zhang, H. Kang, X. Sun, S. Yin, H. Du, N. Yamanaka, W. Gapare, H. Wu and C. LiU (2012): Phylogeography of Quercus variabilis based on chloroplast DNA sequence in East Asia: multiple glacial refugia and Mainland-migrated island population. PloS One. DOI 10.1371/journal.pone.0047268.

ChybiRko, M. I. and J. I. STEPKIN (2009): Report on the epidemiological situation in the city of Voronezh in 2008.: Rospotrebnadzor in Voronezh region, Voronezh (in Russian).

Galvan, J., L. Valledor, F. Gonzalez, R. Navarro Cerrilo and J. JoRRIN-Novo (2012): Proteomic analysis of Holm oak (Quecus ilex subsp. Ballota [Desf.] Samp.) pollen. J Proteomics 75(9): 2736-2744.

Geras'Kin, S. and D. VASIL'Ev (2005): Assessment anthropogenic impact on the population of Pinus sylvestris L. by methods Bioindication in the area of enterprise storage of radioactive waste. Russ. J. Ecology 4: 275-285.

KALAEV, V. (2000): Cytogenetic monitoring of environmental pollution using plant test - objects: Ph. D.. biol. Sciences. Voronezh. (In Russian)

Kalaev, V., S. Karpova and V. ARTyukhov (2010): Cytogenetic characteristics of weeping birch (Betula pendula Roth) seed progeny in different ecological conditions. Bioremediation, Biodiversity and Bioavailability, Special Issue 1 (Tree and Forest Biodiversity) 4: 77-83.

KalashniK, N. and S. Yasovieva (2012): Analysis of meiotic chromosome aberrations in Siberian spruce (Picea obovata Ledeb.) under conditions of natural and technogenic stress. Russ. J. Ecology 43(6): 440-447.

LAKIN, G. F. (1990): Biometrics. Vyshaia shkola. Moscow.

LIČINA, V., M. F. AKŠIĆ, S. Colić and G. ZEC (2013): A bioassessment of soil nickel genotoxic effect in orchard planted on rehabilitated coalmine overburden. Ecotoxicol Environ Saf. 98: 374-82.

LUOMAJOKI, A. (1996): Adaptation of microsporogenesis of exotic conifers in Finland. Forest Genetics 3(3): 153-160.

MiIller, M. and D. GRILL (1996): Chromosomal aberrations in ozone-impacted spruce as a test of cytological damage in forest trees. Forest Genetics 3(3): 161-166.

Milyutin, L., E. Muratova and A. Larionova (2004): Conifer biodiversity in Mongolia and Adjacent Regions of Russia using morphological, karyological and genetical features. Eurasian J. of Forest Research 7(2): 59-66.

Mullagulov, R., N. RED'KinA and J. IANBAeV (2008): Allosimic polimorfism English oak (Quercus robur (Fagaceae)) in isolated populations on the eastern boundary of the range. Vestnik Orenburgs State University 2: 107-110. (In Russian)
Muratova, E., T. Sedelnikova and A. Pimenov et al. (2007): Karyological analysis of larch species from Siberia and the Far East of Russia. Forest Science and Technology 3(2): 89-94. (In Russian)

Oudalova, A. and S. Geras'KIN (2012): The time dynamics and ecological genetic variation of cytogenetic effects in the Scots pine populations experiencing anthropogenic impact. Biology Bulletin Reviews 2(3): 254-267.

Pavlica, M., V. Besendorfer, J. Rosa and D. Papes Chemosphere (2000): The cytotoxic effect of wastewater from the phosphoric gypsum depot on common oak (Quercus robur 1.) and shallot (Allium cepa var. Ascalonicum). Chemosphere 41(10): 1519-27.

Prus-Glowacki, W., E. Chudzińska, A. WojnickaPoltorak, L. KozACKI and K. FAgIEwicz (2006): Effects of heavy metal pollution on genetic variation and cytological disturbances in the Pinus sylvestris L. population. J Appl Genet. 47(2): 99-108.

Ramiez-Valiente, J., D. Sanchez-Gomez, I. Aranda and F. VAlladares (2010): Phenotypic plasticity and local adaptation in leaf ecophysiological traits of 13 contrasting cork oak populations under different water availabilities. Tree Physiology 30(5): 618-627.

Ribeiro, T., A. Barão, W. Viegas and L. Morais-Cecíli (2008): Molecular cytogenetics of forest trees. Cytogenet Genome Res. 120(3-4): 220-7.

SAns, J., M. Moreno and C. Alliende (1984): The nucleolus and its regulation in meristems under two proliferative kinetics. Cytobios 41(163-164): 181-190.

Silvestrini, M., C. A. Pinto-Maglio, M. I. Zucchi and F. A. DOS SANTOS (2013): Cytogenetics and characterization of microsatellite loci for a South American pioneer tree species, Croton floribundus. Genome 56(12): 743-51.

SimAKov, E. (1983): About postradiation restoration of cytogenetic damage in seedlings of different forms of seed potatoes. Radiobiology. Radioecology 23(5): 703-706.

Sobol', M. (2001): The role of the nucleolus in the reactions of plant cells to the action of physical environmental factors. Cytology and genetics 35(3): 72-84.

SEnkevich, E. (2007): Cytogenetics of Scots pine and birch in the area Novovoronezh on issues environmental impact assessments. Ph. D.. biol. Sciences. Voronezh. (In Russian)

ZHANG, Y. (2013): Molecular characterization and genetic structure of Quercus acutissima germplasm in China using microsatellites. Mol Biol Rep. 40(6): 4083-4090. 